\title{
Accounting
}

\section{The impact of corporate social responsibility on customer loyalty: Empirical study for the case of} Vietnam Airlines

\author{
Thu Anh Hoanga, ${ }^{a}$
}

\author{
Institute of Research and Development, Duy Tan University, Da Nang, 550000, Vietnam \\ ${ }^{b}$ International School, Duy Tan University, Da Nang, 550000, Vietnam

\section{H R O N I C L E}

\section{A B S T R A C T}

\section{Article history:}

Received July 22020

Received in revised format July

262020

Accepted July 292020

Available online

August 12020

Keywords:

Airlines

CSR

Customer loyalty

Vietnam

\begin{abstract}
The objective of this study is to investigate the impact of corporate social responsibility (CSR) on customer loyalty in the case of Vietnam Airlines, the flag carrier in Vietnam, in which CSR is a multidimensional construct including economic, legal, ethical, philanthropic and environmental responsibilities. The study was accomplished by implementing a survey on a sample of 370 Vietnamese passengers using 24 Likert-type items drawn from theoretical literature. The multiple regression model was applied to analyze the impact of five latent independent variables on the dependent variable - customer loyalty. The results indicate that for the case of Vietnam Airlines, all five CSR dimensions significantly and positively affect customer loyalty and legal responsibility should be emphasized as the most important dimension. The findings convey practical implications for airlines to boost customer loyalty by identifying relevant CSR dimensions on which airlines should focus in their corporate strategy.
\end{abstract}

\section{Introduction}

Corporate social responsibility (CSR) has been an issue of social concern as businesses become increasingly aware of the importance of CSR activities and communicate their CSR efforts to society (Bhattacharya \& Sen, 2004). In view of the unique characteristics of aviation industry, CSR is recognized as a corporate strategy for airlines to survive and thrive. First, airlines pollute the atmosphere with millions of tons of emissions and contribute to climate change (Holden, 2005). Eco-friendly airlines can create good impression on stakeholders. Secondly, the growing competition in the aviation industry and the similarity in the services provided have forced airlines to pursue a distinction strategy. Lastly, aviation operation involves the matter of life and death so complying with legal regulations related to safe flying is the matter of being viewed as reliable and trustworthy airlines. Studies in airline industry and other business sectors in developed countries have evidenced that customers usually have positive attitude and perception toward responsible businesses and are willing to reward CSR behavior by reusing the service or engaging in positive word-of-mouth (Asatryan, 2012; Diallo \& Lambey-Checchin, 2016; Dimitriadis \& Zilakaki, 2019; Galbreath, 2010; Gürlek et al., 2017; Hagmann et al., 2015; Khairat \& Maher, 2016; Latif et al., 2020; S. S. Lee et al., 2019; Martínez et al., 2014; Moisescu, 2017; Öberseder et al., 2013; Salmones et al., 2005; Servera-Francés \& Piqueras-Tomás, 2019; Vo et al., 2019). In Vietnam, corporate social responsibility has not yet received considerable attention from researchers. Very few studies could be found in banking, telecom and diary industries. However, the study scope has been limited to CSR practice reporting and

* Corresponding author. Tel.: +84 994183363

E-mail address: hoanganhthu1@dtu.edu.vn (T. A. Hoang) 
research on the relationship between CSR and customer behavior is still rare. So far, there has been no research on CSR in aviation sector, even though Vietnamese aviation industry is ranked as one of five fastest-growing markets in terms of additional passengers per year according to IATA's forecast (IATA, 2016). Therefore, the purpose of this study is to investigate the influence of CSR on customer loyalty in Vietnamese aviation industry with the empirical study of Vietnam Airlines - the flag carrier of Vietnam - with the hope that findings from the study could be used as the basis for managerial implications for suitable CSR activities to help Vietnamese airlines gain positive recognition and expand their customer base in the future.

\section{Literature review and hypothesis development}

\subsection{Corporate Social Responsibility}

Corporate social responsibility as expressed by Howard R. Bowen in 1953's publication of Social Responsibilities of the Businessman is a fundamental morality that a company behaves toward society and other stakeholders. Since then, there have been different definitions about CSR. However, Dahlsrud (2008) concluded t "even though there are many available definitions, they are predominantly congruent which makes the lack of one universally accepted definition less problematic". The best known is Carroll's approach which conceptualizes total CSR as a pyramid framework constituted by four categories including economic, legal, ethical and philanthropic responsibilities (Carroll, 1991). Economic responsibility is the primary dimension by which company is responsible for providing goods and services for consumers and ensuring maximum profit for shareholders. Legal dimension, the next layer on the pyramid, states that company is expected to comply with laws and regulations while pursuing their economic missions. Together with economic responsibility, legal responsibility makes the basic principles of corporate responsibilities. At a higher layer, ethical dimension encompasses activities that stakeholders expect or prohibit even though they are not codified into laws and philanthropic dimension embraces actions that company engages in as a good corporate citizen for human well-being. Besides these four dimensions, in view of the specific characteristics of aviation industry, environmental responsibility has emerged as the fifth dimension because airlines have caused considerable environmental impact and are under pressure to lessen environmental harm and apply green initiatives in their business activities. Previous studies have proved that environmental responsibility is crucial to elicit positive attitude and loyalty of eco-conscious passengers towards green airlines (Abdullah et al., 2016; Hagmann et al., 2015; Han et al., 2019; Lynes \& Andrachuk, 2008). In some studies, researchers have modified the conventional Carroll' s pyramid model by integrating the environmental dimension when investigating the impact of CSR on customer behavior (Chung et al., 2015; Kim et al., 2020; S. S. Lee et al., 2019). Thus, in this paper, CSR is a multi-dimensional construct including economic, legal, ethical, philanthropic and environmental categories.

\subsection{CSR at Vietnam Airlines}

As the flag carrier of Vietnamese aviation industry, Vietnam Airlines is a 4-star airline certified by Skytrax and recorded in top 50 best listed companies by Forbes Vietnam. In 2019, it gained 2 prestigious awards including World's Leading Cultural Airline and World's Leading Airline - Premium Economy Class by World Travel Awards. During its business course, the airline strives to increase sustainable benefit to shareholders, ensures corporate governance, enhances operational efficiency and adopts multiple initiatives to enhance fleet operational efficiency with optimal costs. For the legal dimension, Vietnam Airlines pays tax in a fairly manner, fully complies with laws and regulations stipulated by the State and the Civil Aviation Authority of Vietnam and conforms to international conventions on safe flying by obtaining IOSA certificate. The carrier tries to be transparent in business management and treats its employees and customers ethically and honestly. In 2018, Vietnam Airlines was ranked 26 on the Top 100 best places to work in Vietnam and its Net Promoter Score in 2019 reached 23 points relatively high compared to the industry average ( 8 points - according to IATA assessment on Asia and Europe routes). As for philanthropic responsibility, the company actively participates in donation activities, builds houses for impoverished families and joins prestigious domestic and international organizations to address issues of public concerns such as performing surgeries for children and training doctors. The company also places environmental responsibility at top priority and carries out initiatives to protect the environment. In recent years, the airline has invested in new generation fleet (Boeing 787-9, Airbus A350-900, Airbus A321neo) featuring with less fuel consumption, carbon emission and noise pollution and applied SAFRAN fuel efficient software (Vietnam Airlines, 2020).

\subsection{Customer loyalty}

Customer loyalty is defined by the American Marketing Association as "the situation in which a consumer generally buys the same manufacturer-originated product or service repeatedly over time rather than buying from multiple suppliers". However, loyalty is not just about repeated purchase because regular procurement of a certain brand may be due to inertia for branding or because of barriers preventing customers from turning to other brands (Reichheld, 2003). 
Oliver defines true loyalty as a deep commitment to continuing purchasing a favorite product or service in the future, regardless of marketing efforts to generate a changing behavior (Oliver, 1999). Customer loyalty includes two categories: (1) behavioral loyalty, (2) attitudinal loyalty. According to (Fullerton, 2005; Kumar et al., 2006), behavioral loyalty ensures that customer loyalty can be converted into actual purchasing behavior. Attitudinal loyalty is the kind of loyalty in which customers are psychologically attached to the company, willing to recommend it to others and engage in positive word-of-mouth communication (Griffin, 2002). Although attitudinal loyalty does not guarantee that customers will buy goods, the spread of word of mouth can create a positive image of the business to others and generates a positive outcome (Kuusik, 2007).

\subsection{Hypotheses development}

CSR has had empirical testing in the context of many industries and CSR efforts have been proved to enhance customer loyalty (Maignan, 2001; Mandhachitara \& Poolthong, 2011; Martínez et al., 2013, 2014; Moisescu, 2017; Rashid et al., 2015; Salmones et al., 2005). Previous research of (Gürlek et al., 2017) evidenced that economic responsibility is considered as the most fundamental responsibility and customers are willing to be loyal to financially successful businesses (Hsu, 2018; C. Y. Lee, 2019; Stanisavljević, 2017). Besides, paying taxes in a fairly manner (Moisescu, 2017), fully complying with legal regulations and refraining itself from bending the laws even if this helps improve business performance (Arli \& Lasmono, 2010; Maignan, 2001), and especially in the case of aviation industry, the extent to which an airline respecting environmental regulations and international conventions (Asatryan, 2012; Khairat \& Maher, 2016) have been proved to have positive impact on customer loyalty. Research of (Asatryan, 2012; Chen et al., 2012) also proved that treating ethically to consumers, protecting consumer right, participating in charity activities and environmental protection would increase behavioral and attitudinal loyalty. (Cho et al., 2017) found that ethical and philanthropic CSR positively influences the patronage for the service of Asiana Airlines, under the mediating role of corporate image and customer trust. Another example of the positive impact of CSR in airline on customer loyalty is the case of the high-flying Southwest Airlines whose philosophy is "the employee comes first" having built their success for its impressive customer service provided by a well-treated workforce (Martin et al., 2009). Due to the characteristics of airline industry, environmental responsibility is one of the most frequently analyzed CSR components and proved to boost corporate imaged and customer loyalty intentions (Han et al., 2019) since a green airline elicits positive attitude and is perceived as an airline of good choice (Hagmann et al., 2015).

Based on the previous studies, the current research proposes the following hypotheses:

H1: Economic responsibility positively influences customer loyalty.

H2: Legal responsibility positively influences customer loyalty.

H3: Ethical responsibility positively influences customer loyalty.

H4: Philanthropic responsibility positively influences customer loyalty.

H5: Environmental responsibility positively influences customer loyalty.

\section{Methodology}

\subsection{Samples and data collection}

The study was carried out from June 1 to June 20, 2020 in the departure lounge of Da Nang international airport after the social distancing restriction on aircraft had been lifted and it was conducted on Vietnamese passengers who had experienced flying with Vietnam Airlines and continued using the service of Vietnam Airlines this time. Three field researchers explained the purpose of the study and invited Vietnam Airlines passengers to participate the survey. Upon their consent, the participants received the questionnaires and answered them in approximately 15 minutes. Of 400 questionnaires distributed, the field researchers collected 390, representing a response rate of $97.50 \%$. After examination, we excluded 20 questionnaires from the analysis because of missing data. Thus, a total of 370 samples, constituting a $92.50 \%$ distribution ratio, were applied in this study.

Table 1

Sample descriptive statistics

\begin{tabular}{llll}
\hline Gender & & Marital Status & \\
\hline Male & $178(48.1 \%)$ & Single & Married \\
Female & $192(51.9 \%)$ & Monthly Income & \\
Age & & Under 5 million dongs & $236(63.8 \%)$ \\
$20-29$ & $134(36.2 \%)$ & $5-10$ million dongs & $30(8.1 \%)$ \\
$30-39$ & $140(37.8 \%)$ & $10-15$ million dongs & $138(37.3 \%)$ \\
$40-49$ & $58(15.7 \%)$ & $15-20$ million dongs & $140(37.8 \%)$ \\
$50-59$ & $22(5.9 \%)$ & Over 20 million dongs & $47(12.7 \%)$ \\
Over 60 & $16(4.3 \%)$ & & \\
\hline
\end{tabular}

3.2 Measurement scales 
The questionnaire included 24 Likert-type items (ranging from $1=$ "strongly disagree" to $5=$ "strongly agree") to measure 5 CSR dimensions - independent variables - including economic, legal, ethical, philanthropic and environmental responsibilities and customer loyalty - dependent variable. For the measurement of economic, legal, ethical and philanthropic CSR dimensions, the author adopted 16 items from (Cho et al., 2017) and for environmental dimension, the author adopted 4 items from (Moisescu, 2017). Four items for customer loyalty were adopted from (Nguyen \& LeBlanc, 2001).

Economic responsibility (ECOCSR) (4 items): generating much employment impact, trying to save operating cost, being committed to long-term economic growth, contributing to economic development through profit-making.

Legal responsibility (LEGCSR) (4 items): complying with international air transport-related laws, being committed to operate business legally, complying with customer protection laws for customers, complying with airline service-related regulations.

Ethical responsibility (ETHCSR) (4 items): trying to be transparent management, trying to be a reliable company with correct moral principles, providing customers with accurate corporate management information, not releasing false and exaggerated advertisements.

Philanthropic responsibility (PHICSR) (4 items): providing variety of donations, developing a campaign for helping the needy, being committed to build a better community, conducting various social responsible activities through fundraising.

Environmental responsibility (ENVCSR) (4 items): doing everything possible to reduce negative effects on the environment, striving to minimize the consumption of resources, working diligently to use environmentally friendly materials, and being concerned with waste management and recycling activities.

Customer loyalty (LOYALTY) (4 items): If I had needed flying services now, Vietnam Airlines would be my first choice, I will continue to fly with Vietnam Airlines, I would recommend Vietnam Airlines as the best airlines in Vietnam, I would encourage friends and relatives to fly with Vietnam Airlines.

\section{Results and discussion}

\subsection{Reliability Test}

Table 2 shows the result of reliability test for the dependent and independent variables. In this study, all the Cronbach's alpha coefficients exceed the minimum cutoff level of .60. Thus, the items measuring the variables are considered acceptable and the instruments are accepted for the reliability test.

\section{Table 2}

Mean Scores and Analysis of Internal Consistency

\begin{tabular}{|c|c|c|c|c|}
\hline Variables & No. of Items & Mean & $\mathrm{SD}$ & Cronbach's Alpha \\
\hline ECOCSR & 4 & 17.18 & 1.459 & .820 \\
\hline LEGCSR & 4 & 14.62 & 2.561 & .926 \\
\hline ETHCSR & 4 & 16.66 & 1.384 & .703 \\
\hline PHICSR & 4 & 19.03 & 1.533 & .888 \\
\hline ENVCSR & 4 & 16.65 & 1.247 & .840 \\
\hline LOYALTY & 4 & 17.40 & 1.568 & .778 \\
\hline
\end{tabular}

\subsection{Exploratory Factor Analysis (EFA)}

The author conducted Exploratory Factor Analysis (EFA), varimax analysis of 20 observed independent variables. The result of EFA on Table 3 shows that $0.5<\mathrm{KMO}=0.743<1$, which means that all variables are related to each other. The Bartlett's test of sphericity (chi-square $=3934.080 ; \mathrm{df}=190 ; \mathrm{p}<.001$ ) indicating correlations in the data set that are appropriate for factor analysis. Cumulative extraction sums of squared loadings $=70.087 \%>50 \%$.

\section{Table 3}

KMO and Bartlett's Test 
Table 4

Rotated Component Matrix

\begin{tabular}{|c|c|c|c|c|c|}
\hline & \multicolumn{5}{|c|}{ Component } \\
\hline & 1 & 2 & 3 & 4 & 5 \\
\hline LEGCSR3 & .914 & & & & \\
\hline LEGCSR2 & .906 & & & & \\
\hline LEGCSR4 & .895 & & & & \\
\hline LEGCSR1 & .894 & & & & \\
\hline PHICSR4 & & .882 & & & \\
\hline PHICSR2 & & .881 & & & \\
\hline PHICSR3 & & .872 & & & \\
\hline PHICSR1 & & .809 & & & \\
\hline ENVCSR3 & & & .891 & & \\
\hline ENVCSR2 & & & .831 & & \\
\hline ENVCSR4 & & & .812 & & \\
\hline ENVCSR1 & & & .739 & & \\
\hline ECOCSR3 & & & & .881 & \\
\hline ECOCSR2 & & & & .839 & \\
\hline ECOCSR4 & & & & .739 & \\
\hline ECOCSR1 & & & & .733 & \\
\hline ETHCSR1 & & & & & .742 \\
\hline ETHCSR3 & & & & & .723 \\
\hline ETHCSR4 & & & & & .719 \\
\hline ETHCSR2 & & & & & .679 \\
\hline
\end{tabular}

The results of the rotated component matrix show that 20 observed variables are grouped into 5 latent variables and all observed variables have factor loadings which are greater than 0.5 .

\subsection{Analysis of factors affecting customer loyalty for Vietnam Airlines}

After testing the reliability and analyzing EFA, the author checked Pearson's correlation coefficient to check the correlation between the dependent and independent variables.

Table 5

Correlations

\begin{tabular}{|c|c|c|c|c|c|c|c|}
\hline & & LOYALTY & ECOCSR & LEGCSR & ETHCSR & PHICSR & ENVCSR \\
\hline \multirow{3}{*}{ LOYALTY } & Pearson Correlation & 1 & $.173^{* *}$ & $.355^{* *}$ & $.381^{* *}$ & $.298^{* *}$ & $.156^{* *}$ \\
\hline & Sig. (2-tailed) & & .001 & .000 & .000 & .000 & .003 \\
\hline & $\mathrm{N}$ & 370 & 370 & 370 & 370 & 370 & 370 \\
\hline \multirow{3}{*}{ ECOCSR } & Pearson Correlation & $.173^{* *}$ & 1 & .087 & $.123^{*}$ & .034 & -.031 \\
\hline & Sig. (2-tailed) & .001 & & .094 & .018 & .513 & .559 \\
\hline & $\mathrm{N}$ & 370 & 370 & 370 & 370 & 370 & 370 \\
\hline \multirow{3}{*}{ LEGCSR } & Pearson Correlation & $.355^{* *}$ & .087 & 1 & $.134^{* *}$ & .053 & -.062 \\
\hline & Sig. (2-tailed) & .000 & .094 & & .010 & .309 & .234 \\
\hline & $\mathrm{N}$ & 370 & 370 & 370 & 370 & 370 & 370 \\
\hline \multirow{3}{*}{ ETHCSR } & Pearson Correlation & $.381^{* *}$ & $.123^{*}$ & $.134^{* *}$ & 1 & $.158^{* *}$ & $.138^{* *}$ \\
\hline & Sig. (2-tailed) & .000 & .018 & .010 & & .002 & .008 \\
\hline & $\mathrm{N}$ & 370 & 370 & 370 & 370 & 370 & 370 \\
\hline \multirow{3}{*}{ PHICSR } & Pearson Correlation & $.298^{* *}$ & .034 & .053 & $.158^{* *}$ & 1 & .047 \\
\hline & Sig. (2-tailed) & .000 & .513 & .309 & .002 & & .363 \\
\hline & $\mathrm{N}$ & 370 & 370 & 370 & 370 & 370 & 370 \\
\hline \multirow{3}{*}{ ENVCSR } & Pearson Correlation & $.156^{* *}$ & -.031 & -.062 & $.138^{* *}$ & .047 & 1 \\
\hline & Sig. (2-tailed) & .003 & .559 & .234 & .008 & .363 & \\
\hline & $\mathrm{N}$ & 370 & 370 & 370 & 370 & 370 & 370 \\
\hline
\end{tabular}

**. Correlation is significant at the 0.01 level (2-tailed).

*. Correlation is significant at the 0.05 level (2-tailed).

Table 5 shows that there were correlations between the dependent variable (loyalty) and the independent variables so the author used the multiple regression model to analyze the multiple linear regression between the dependent and independent variables.

Table 6

Model Summary

\begin{tabular}{lcccc}
\hline Model & $\mathrm{R}$ & $\mathrm{R}$ Square & Adjusted R Square & Std. Error of the Estimate \\
\hline 1 & $.565^{\mathrm{a}}$ & .320 & .310 & Durbin-Watson \\
\hline
\end{tabular}

a. Predictors: (Constant), ENVCSR, ECOCSR, PHICSR, LEGCSR, ETHCSR

b. Dependent Variable: LOYALTY 
Table 7

ANOVA

\begin{tabular}{llcccc}
\hline Model & & Sum of Squares & Df & Mean Square & S \\
\hline \multirow{2}{*}{1} & Regression & 18.113 & 5 & 3.623 & .106 \\
& Residual & 38.575 & 364 & $.000^{\mathrm{b}}$ & \\
\cline { 2 - 5 } & Total & 56.687 & 369 & & \\
\hline
\end{tabular}

a. Dependent Variable: LOYALTY

b. Predictors: (Constant), ENVCSR, ECOCSR, PHICSR, LEGCSR, ETHCSR

The result shows that adjusted $\mathrm{R}$ Square $=0.310$, F-test $($ ANOVA) represents the significance level. $=0.000$; therefore, the regression model is suitable. Table 8 presents the result of the multiple linear regression as follows:

Table 8

Multiple linear regression analysis result

\begin{tabular}{|c|c|c|c|c|c|c|c|c|}
\hline & & \multicolumn{2}{|c|}{$\begin{array}{c}\text { Unstandardized } \\
\text { Coefficients }\end{array}$} & \multirow{2}{*}{$\begin{array}{c}\begin{array}{c}\text { Standardized } \\
\text { Coefficients }\end{array} \\
\text { Beta } \\
\end{array}$} & \multirow[t]{2}{*}{$\mathbf{T}$} & \multirow[t]{2}{*}{ Sig. } & \multicolumn{2}{|c|}{ Collinearity Statistics } \\
\hline & & B & Std. Error & & & & Tolerance & VIF \\
\hline \multirow{6}{*}{1} & (Constant) & .088 & .388 & & .226 & .821 & & \\
\hline & ECOCSR & .116 & .047 & .108 & 2.478 & .014 & .978 & 1.023 \\
\hline & LEGCSR & .187 & .027 & .305 & 6.950 & .000 & .970 & 1.031 \\
\hline & ETHCSR & .310 & .051 & .273 & 6.087 & .000 & .928 & 1.078 \\
\hline & PHICSR & .234 & .045 & .228 & 5.213 & .000 & .973 & 1.028 \\
\hline & ENVCSR & .163 & .055 & .130 & 2.959 & .003 & .972 & 1.029 \\
\hline
\end{tabular}

a. Dependent Variable: LOYALTY

The multiple linear regression results show that customer loyalty in Vietnam Airlines is significantly impacted by all five CSR dimensions. Based on the size of standardized coefficient beta, we could find that the most important effect on customer loyalty is given by how customers perceive the airline commitment to operate the business legally and comply with the state and international air transport-related laws (Beta $=.305 ; \mathrm{p}<.001$ ), followed by how customers perceive the carrier treats its customers ethically and engages to being a reliable and transparent airline (Beta $=.237 ; \mathrm{p}<.001)$; contributes to the well-being of the society $(B e t a=.228 ; \mathrm{p}<.001)$, protects the environment $(\mathrm{Beta}=.130 ; \mathrm{p}=.003)$, and contributes to economic development through profit making and generates employment impact $(\mathrm{Beta}=.108 ; \mathrm{p}=.014)$.

Findings from the study are consistent with previous studies on the impact of CSR activities on customer loyalty in airline industry of other countries. (Asatryan, 2012; Chen et al., 2012; Khairat \& Maher, 2016) previously showed that an airline which demonstrates that it respects customers and employees, treats customers ethically and transparently, conducts the business in accordance with laws and policies stipulated by government and international conventions, provides safe and reliable transportation service, protects the environment and spends part of its profit on charity funding... could foster customer loyalty. These results are consistent with the output of the current research which also shows that ethical, legal, philanthropic and environmental responsibility has significant impacts on customer loyalty. Besides, the fact that being a financially strong airline with sustainable development has been proved to be an airline of wise choice in customers' opinion (Park, 2019; Park et al., 2015 ) is reaffirmed in the current study when economic responsibility is proved to be a predictor of customer loyalty.

\section{Conclusions and implications}

The current study has revealed that in the case of Vietnam Airlines, customer loyalty is significantly impacted by the extent to which the airline engages in responsible activities and expresses itself as a good citizen. The study results show that all CSR dimensions including economic, legal, ethical, philanthropic and environmental responsibilities have positive and significant influence on customer loyalty. However, the degrees of these impacts on customer loyalty vary. The fact that legal CSR has the strongest influence on customers implies that Vietnamese passengers emphasize the importance of laws compliance in air transportation when regulations on safety and health for passengers and crew have been proved to work efficiently in preventing the spread of disease during the COVID - 19 pandemic in Vietnam recently. Ethical and philanthropic responsibilities are relevant to customer loyalty and have stronger effect than environmental and economic responsibilities.

The fact that CSR activities are highly appreciated by customers elicits that Vietnam Airlines should communicate these activities to stakeholders so as to enhance its customer base loyalty and reinforce its position as the flag carrier of Vietnam. It is extremely significant in the current context when competition in Vietnamese aviation industry is expected to increase in the near future. However, the limitation of this study is that it is only investigating the case of Vietnam Airlines. In the future, studies conducted on all airlines of Vietnamese aviation industry are encouraged to verify the results of this study. 
Abdullah, M.-A., Chew, B.-C., \& Hamid, S.-R. (2016). Benchmarking key success factors for the future green airline industry. Procedia - Social and Behavioral Sciences, 224, 246-253.

Arli, D. I., \& Lasmono, H. K. (2010). Consumers' perception of corporate social responsibility in a developing country. International Journal of Consumer Studies, 34(1), 46-51.

Asatryan, R. (2012). The effect of CSR initiatives on customer loyalty in the airline industry. Mathematics and Computers in Contemporary Sciences, 66-71.

Carroll, A. B. (1991). The pyramid of corporate social responsibility: Toward the moral management of organizational stakeholders. Business Horizon, 34(4), 39-48.

Chen, F., Chang, Y., \& Lin, Y. (2012). Journal of air transport management customer perceptions of airline social responsibility and its effect on loyalty. Journal of Air Transport Management, 20, 49-51.

Cho, S.-J., Song, H.-J., Lee, C.-K., \& Lee, S.-K. (2017). The impact of CSR on airline passengers' corporate image, customer trust, and behavioral intentions: an empirial analysis of safety activity. Korean Journal of Hospitality \& Tourism, 26(4), 87106.

Chung, K.-H., Yu, J.-E., Choi, M.-G., \& Shin, J.-I. (2015). The effects of CSR on customer satisfaction and loyalty in China: The moderating role of corporate image. Journal of Economics, Business and Management, 3(5), $542-547$.

Dahlsrud, A. (2008). How corporate social responsibility is defined: An analysis of 37 definitions. Corporate Social Responsibility and Environmental Management, 15(1), 1-13.

Diallo, M. F., \& Lambey-Checchin, C. (2016). Relationships between CSR and customer loyalty: What lessons for retailers? Proceedings of 11th RIODD Conference, Energie, Environnement et Mutations Sociales, 2(Immd), 1-20.

Dimitriadis, E., \& Zilakaki, E. (2019). The effect of corporate social responsibility on customer loyalty in mobile telephone companies. International Journal of Economics and Business Administration, 7(4), 433-450.

Fullerton, G. (2005). The impact of brand commitment on loyalty to retail service brands. Canadian Journal of Administrative Sciences, 22(2), 97-110.

Galbreath, J. (2010). How does corporate social responsibility benefit firms? Evidence from Australia. European Business Review, 22(4), 411-431.

Griffin, J. (2002). Customer loyalty: how to earn it, how to keep it. Jossey-Bass.

Gürlek, M., Düzgün, E., \& Uygur, S. M. (2017). How does corporate social responsibility create customer loyalty? the role of corporate image. Social Responsibility Journal, 13(3), 409-427.

Hagmann, C., Semeijn, J., \& Vellenga, D. B. (2015). Exploring the green image of airlines: Passenger perceptions and airline choice. Journal of Air Transport Management, 43, 37-45.

Han, H., Yu, J., \& Kim, W. (2019). Environmental corporate social responsibility and the strategy to boost the airline's image and customer loyalty intentions. Journal of Travel and Tourism Marketing, 36(3), 371-383.

Hsu, S.-L. (2018). The effects of corporate social responsibility on corporate image, customer satisfaction and customer Loyalty: An empirical study on the telecommunication industry. The International Journal of Social Sciences and Humanities Invention, 5(5), 4693-4703.

IATA. (2016). IATA Forecasts Passenger Demand to Double Over 20 Years.

Khairat, G., \& Maher, A. (2016). The influence of airlines' corporate social responsibility on customer loyalty. Journal of Association of Arab Universities for Tourism and Hospitality, 13(2), 71-92.

Kim, Y., Lee, S. S., \& Roh, T. (2020). Taking Another Look at Airline CSR : How Required CSR and Desired CSR A ff ect Customer Loyalty in the Airline Industry.

Kumar, V., Shah, D., \& Venkatesan, R. (2006). Managing retailer profitability — one customer at a time ! Journal of Retailing, 82(4), 277-294.

Kuusik, A. (2007). Affecting customer loyalty: Do different factors have various influences in different loyalty levels? University of Tartu, Faculty of Economics \& Business Administration Working Paper Series, 58, 3-29.

Latif, K. F., Pérez, A., \& Sahibzada, U. F. (2020). Corporate social responsibility (CSR) and customer loyalty in the hotel industry: A cross-country study. International Journal of Hospitality Management, 89(May), 102565.

Lee, C. Y. (2019). Does corporate social responsibility influence customer loyalty in the Taiwan insurance sector? The role of corporate image and customer Satisfaction. Journal of Promotion Management, 25(1), 43-64.

Lee, S. S., Kim, Y., \& Roh, T. (2019). Modified pyramid of CSR for corporate image and customer loyalty: Focusing on the moderating role of the CSR experience. Sustainability (Switzerland), 11(17).

Lynes, J. K., \& Andrachuk, M. (2008). Motivations for corporate social and environmental responsibility: A case study of Scandinavian Airlines. Journal of International Management, 14(4), 377-390.

Maignan, I. (2001). Consumers' perceptions of corporate social responsibilities: A cross-cultural comparison. Journal of Business Ethics, 30(2), 57-72.

Mandhachitara, R., \& Poolthong, Y. (2011). A model of customer loyalty and corporate social responsibility. Journal of Services Marketing, 25(2), 122-133.

Martin, J. D., Petty, J. W., \& Wallace, J. S. (2009). Value Based Management with Corporate Social Responsibility (Second). 
Oxford University Press.

Martínez, P., Pérez, A., \& del Bosque, I. R. (2014). CSR influence on hotel brand image and loyalty. Academia Revista Latinoamericana de Administracion, 27(2), 267-283.

Martínez, P., Pérez, A., \& Rodríguez del Bosque, I. (2013). Measuring Corporate Social Responsibility in tourism: Development and validation of an efficient measurement scale in the hospitality industry. Journal of Travel and Tourism Marketing, 30(4), 365-385.

Moisescu, O. I. (2017). From CSR to customer loyalty: An empirical investigation in the retail banking industry of a developing country. Scientific Annals of Economics and Business, 64(3), 307-323.

Nguyen, N., \& LeBlanc, G. (2001). Corporate image and corporate reputation in customers' retention decisions in services. Journal of Retailing and Consumer Services, 8, 227-236.

Öberseder, M., Schlegelmilch, B. B., \& Murphy, P. E. (2013). CSR practices and consumer perceptions. Journal of Business Research, 66(10), 1839-1851.

Oliver, R. L. (1999). Whence Consumer Loyalty? Journal of Marketing, 63, 33-44.

Park, E. (2019). Corporate social responsibility as a determinant of corporate reputation in the airline industry. Journal of Retailing and Consumer Services, 47(November 2018), 215-221.

Park, E., Lee, S., Kwon, S. J., \& del Pobil, A. P. (2015). Determinants of behavioral intention to use South Korean Airline Services: Effects of service quality and corporate social responsibility. Sustainability (Switzerland), 7(9), 12106-12121.

Rashid, N. R. N. A., Khalid, S. A., \& Rahman, N. I. A. (2015). Environmental corporate social responsibility (ECSR): Exploring its influence on customer Lloyalty. Procedia Economics and Finance, 31(15), 705-713.

Reichheld, F. F. (2003). The One Number You Need to Grow. Harvard Business Review, December, $46-54$.

Salmones, M. D. M. G. de los, Crespo, A. H., \& Del Bosque, I. R. (2005). Influence of corporate social responsibility on loyalty and valuation of services. Journal of Business Ethics, 61(4), 369-385.

Servera-Francés, D., \& Piqueras-Tomás, L. (2019). The effects of corporate social responsibility on consumer loyalty through consumer perceived value. Economic Research-Ekonomska Istrazivanja , 32(1), 66-84.

Stanisavljević, M. (2017). Does customer loyalty depend on corporate social responsibility? Naše Gospodarstvo/Our Economy, 63(1), 38-46.

Vietnam Airlines. (2020). Vietnam Airlines Annual report. Vietnam Airlines.

Vo, T. T., Xiao, X., \& Ho, S. Y. (2019). How does corporate social responsibility engagement influence word of mouth on Twitter? Evidence from the Airline Industry. Journal of Business Ethics, 157(2), 525-542.

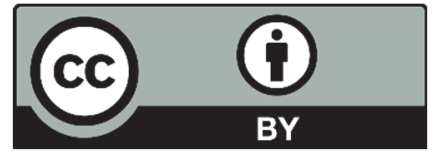

(C) 2020 by the authors; licensee Growing Science, Canada. This is an open access article distributed under the terms and conditions of the Creative Commons Attribution (CC-BY) license (http://creativecommons.org/licenses/by/4.0/). 